\title{
Identifying precursors and aqueous organic aerosol formation pathways during the SOAS campaign
}

\author{
Neha Sareen ${ }^{1}$, Annmarie G. Carlton ${ }^{1, \mathrm{a}}$, Jason D. Surratt ${ }^{2}$, Avram Gold ${ }^{2}$, Ben Lee ${ }^{3}$, Felipe D. Lopez-Hilfiker ${ }^{3, \mathrm{~b}}$, \\ Claudia Mohr ${ }^{3, \mathrm{c}}$, Joel A. Thornton ${ }^{3}$, Zhenfa Zhang ${ }^{2}$, Yong B. Lim ${ }^{1, \mathrm{~d}}$, and Barbara J. Turpin ${ }^{2}$ \\ ${ }^{1}$ Department of Environmental Sciences, Rutgers University, 14 College Farm Road, New Brunswick, \\ New Jersey 08901, USA \\ ${ }^{2}$ Department of Environmental Sciences and Engineering, Gillings School of Public Health, University of \\ North Carolina at Chapel Hill, Chapel Hill, NC 27599, USA \\ ${ }^{3}$ Department of Atmospheric Sciences, University of Washington, Seattle, WA 98195, USA \\ ${ }^{a}$ now at: Department of Chemistry, University of California, Irvine, CA 92697, USA \\ ${ }^{b}$ now at: Laboratory of Atmospheric Chemistry, Paul Scherrer Institute, 5232 Villigen PSI, Switzerland \\ ${ }^{c}$ now at: Institute of Meteorology and Climate Research, Atmospheric Aerosol Research, Karlsruhe Institute \\ of Technology, Karlsruhe, Germany \\ ${ }^{d}$ now at: Center for Environment, Health and Welfare Research, Korea Institute of Science and Technology, \\ Seoul 02792, Republic of Korea
}

Correspondence to: Neha Sareen (neha.sareen15@gmail.com) and Barbara J. Turpin (bjturpin@email.unc.edu)

Received: 8 March 2016 - Published in Atmos. Chem. Phys. Discuss.: 5 April 2016

Revised: 24 October 2016 - Accepted: 24 October 2016 - Published: 21 November 2016

\begin{abstract}
Aqueous multiphase chemistry in the atmosphere can lead to rapid transformation of organic compounds, forming highly oxidized, low-volatility organic aerosol and, in some cases, light-absorbing (brown) carbon. Because liquid water is globally abundant, this chemistry could substantially impact climate, air quality, and health. Gas-phase precursors released from biogenic and anthropogenic sources are oxidized and fragmented, forming water-soluble gases that can undergo reactions in the aqueous phase (in clouds, fogs, and wet aerosols), leading to the formation of secondary organic aerosol $\left(\mathrm{SOA}_{\mathrm{AQ}}\right)$. Recent studies have highlighted the role of certain precursors like glyoxal, methylglyoxal, glycolaldehyde, acetic acid, acetone, and epoxides in the formation of $\mathrm{SOA}_{\mathrm{AQ}}$. The goal of this work is to identify additional precursors and products that may be atmospherically important. In this study, ambient mixtures of watersoluble gases were scrubbed from the atmosphere into water at Brent, Alabama, during the 2013 Southern Oxidant and Aerosol Study (SOAS). Hydroxyl $(\mathrm{OH} \bullet$ ) radical oxidation experiments were conducted with the aqueous mixtures collected from SOAS to better understand the formation of SOA through gas-phase followed by aqueous-phase chemistry. To-
\end{abstract}

tal aqueous-phase organic carbon concentrations for these mixtures ranged from 92 to $179 \mu \mathrm{M}-\mathrm{C}$, relevant for cloud and fog waters. Aqueous $\mathrm{OH}-$ reactive compounds were primarily observed as odd ions in the positive ion mode by electrospray ionization mass spectrometry (ESI-MS). Ultra highresolution Fourier-transform ion cyclotron resonance mass spectrometry (FT-ICR-MS) spectra and tandem MS (MSMS) fragmentation of these ions were consistent with the presence of carbonyls and tetrols. Products were observed in the negative ion mode and included pyruvate and oxalate, which were confirmed by ion chromatography. Pyruvate and oxalate have been found in the particle phase in many locations (as salts and complexes). Thus, formation of pyruvate/oxalate suggests the potential for aqueous processing of these ambient mixtures to form $\mathrm{SOA}_{\mathrm{AQ}}$.

\section{Introduction}

Aqueous multiphase chemistry has the potential to alter the climate-relevant properties and behavior of atmospheric aerosols. It is well established that a major pathway for sec- 
ondary organic aerosol (SOA) formation is via the partitioning of semi-volatile products of gas-phase photochemical reactions into preexisting organic particulate matter (Seinfeld and Pankow, 2003). Semi-volatile partitioning theory is widely used to model SOA (Odum et al., 1996; Seinfeld and Pankow, 2003; Donahue et al., 2006). However differences between organic aerosol mass/properties predicted via this formation mechanism and those measured in the atmosphere suggest that other processes (e.g., aqueous chemistry) may also contribute (Foley et al., 2010; Hallquist et al., 2009).

Recent studies have highlighted the importance of water-soluble organic gases (WSOGs), liquid water, and condensed-phase reactions to SOA formation and properties (Ervens et al., 2011; Monge et al., 2012; Carlton and Turpin, 2013). Biogenic and anthropogenic gas-phase precursors are oxidized to form WSOGs such as glyoxal, methylglyoxal, glycolaldehyde, and acetone (Spaulding et al., 2003). These WSOGs are too volatile to form SOA through absorptive partitioning, but they can undergo aqueous reactions in clouds, fogs, and wet aerosols to form low-volatility products and "aqueous" SOA (SOA $\mathrm{AQ}$ ) (Blando and Turpin, 2000; Ervens et al., 2004, 2008, 2011; Kroll et al., 2005; Liggio et al., 2005; Lim et al., 2005; Heald et al., 2006; Loeffler et al., 2006; Sorooshian et al., 2006; Volkamer et al., 2006, 2007; De Haan et al., 2009a; El Haddad et al., 2009; Rossignol et al., 2014). Inclusion of aqueous chemistry of clouds, fogs, and wet aerosols in models and experiments helps to explain discrepancies in atmospheric observations of SOA that are not explained by semi-volatile partitioning theory, particularly high atmospheric $\mathrm{O} / \mathrm{C}$ ratios; enrichment of organic aerosol aloft; and formation of oxalate, sulfur-, and nitrogencontaining organics and high-molecular-weight compounds (Kawamura and Ikushima, 1993; Kawamura et al., 1996; Crahan et al., 2004; Kalberer et al., 2004; Herrmann et al., 2005; Altieri et al., 2006; Carlton et al., 2006; Heald et al., 2006; Volkamer et al., 2007, 2009; Nozière and Cordova, 2008; De Haan et al., 2009b; El Haddad et al., 2009; Galloway et al., 2009; Shapiro et al., 2009; Lim et al., 2010; Lin et al., 2010; Nozière et al., 2010; Perri et al., 2010; Sareen et al., 2010; Schwier et al., 2010; Sorooshian et al., 2010; Sun et al., 2010; Ervens et al., 2011, 2013; Lee et al., 2011; Tan et al., 2012; He et al., 2013; Gaston et al., 2014; Ortiz-Montalvo et al., 2014). Although uncertainties are large, modeling studies show that $\mathrm{SOA}_{\mathrm{AQ}}$ is comparable in magnitude to "traditional" SOA (Carlton et al., 2008; Fu et al., 2008, 2009; Gong et al., 2011; Myriokefalitakis et al., 2011; Liu et al., 2012; Lin et al., 2014). However, $\mathrm{SOA}_{\mathrm{AQ}}$ precursors and their chemical evolution remain poorly understood.

Much of what we know about aqueous chemistry leading to $\mathrm{SOA}_{\mathrm{AQ}}$ formation is derived from laboratory studies with single precursors hypothesized to be important; however, the most important precursors for $\mathrm{SOA}_{\mathrm{AQ}}$ formation in the ambient environment may remain unidentified. A small number of studies conducted with ambient mixtures have provided insights into the pathways of $\mathrm{SOA}_{\mathrm{AQ}}$ formation. For example, photochemical oxidation of aerosol filter samples and cloud water from Whistler, British Columbia, suggest that watersoluble organic compounds of intermediate volatility (e.g., cis-pinonic acid) can be important precursors for $\mathrm{SOA}_{\mathrm{AQ}}$ (Lee et al., 2012). Pyruvic acid oxidation experiments on Mt. Tai, China cloud water suggested a slowing of pyruvic acid oxidation presumably due to competition for $\mathrm{OH}$ radicals with the complex dissolved cloud water organics (Boris et al., 2014). However, further ambient measurements are needed to identify precursors important for ambient $\mathrm{SOA}_{\mathrm{AQ}}$ formation in atmospheric waters.

This work reports, for the first time, results of aqueous $\mathrm{OH}$ radical oxidation experiments conducted in ambient mixtures of water-soluble gases. Ambient mixtures were collected in the southeastern US during the Southern Oxidant and Aerosol Study (SOAS) in the summer of 2013; experiments were used to identify water-soluble gases that may serve as precursors of atmospheric aqueous SOA. This region has experienced an overall cooling trend in surface temperature over the second half of the twentieth century, compared to the warming trend observed elsewhere in the US (Robinson et al., 2002; Goldstein et al., 2009; Portmann et al., 2009). Biogenic sources dominate emissions in this region with varying degrees of impact from anthropogenic sources. Measurements by Nguyen et al. (2014) and model results by Carlton and Turpin (2013) indicate the significance of anthropogenic aerosol liquid water (ALW) in this region and support a role for ALW in $\mathrm{SOA}_{\mathrm{AQ}}$ formation. In the southeastern US, photochemistry and abundant liquid water coexist, making it an ideal location to study $\mathrm{SOA}_{\mathrm{AQ}}$ formation through gas-phase followed by aqueous-phase chemistry. The objective of this work is to identify WSOGs important to $\mathrm{SOA}_{\mathrm{AQ}}$ formation. Since $\mathrm{OH}$ oxidation experiments were conducted in dilute solution, we will also identify products expected through cloud/fog processing of ambient WSOG mixtures. Products may differ in aerosols, where solute concentrations are higher, and radical-radical chemistry and acid-catalyzed reactions (e.g., epoxide ring-opening reactions yielding tetrols and organosulfates from isoprene epoxydiol, IEPOX) are important. We expect that aqueous chemistry in clouds, fogs, and wet aerosols is a sink for reactants identified herein and that this work will motivate laboratory studies and chemical modeling of newly identified aerosol/cloud precursors.

\section{Methods}

Samples of ambient water-soluble mixtures collected in mist chambers during the SOAS field study were used to conduct controlled aqueous $\mathrm{OH}$ radical oxidation experiments. Mass spectral techniques were used to tentatively identify compounds with decreasing abundance in aqueous $\mathrm{OH}$ oxidation experiments, but not in control experiments with the aim of identifying new aqueous chemistry precursors for fur- 
ther study. Ion chromatography (IC) was used to identify selected products.

\subsection{Mist chamber field sampling at SOAS (in Brent, AL)}

Water-soluble gases were scrubbed from filtered ambient air at the Centerville ground site in Brent, AL, during SOAS. Samples were collected from 1 June to 14 July 2013 from $1 \mathrm{~m}$ above the sampling station roof through a $1.3 \mathrm{~cm}$ OD Teflon inlet (approximately $1.7 \mathrm{~m}$ in length). Four mist chambers (Anderson et al., 2008a, b; Dibb et al., 1994; Hennigan et al., 2009) were operated in an air-conditioned trailer (indoor temperature: $25^{\circ} \mathrm{C}$ ) at $25 \mathrm{~L} \mathrm{~min}^{-1}$ in parallel for $4 \mathrm{~h}$, typically 2-3 times each day between 07:00 and 19:00 CDT. Particles were removed by passing the ambient air through a pre-baked quartz fiber filter (QFF) (Pall, $47 \mathrm{~mm}$ ) prior to introduction into the mist chamber.

The mist chambers were operated with $25 \mathrm{~mL}$ of $17.5 \pm 0.5 \mathrm{M} \Omega$ ultra-pure water; additional water was added during the run to replace water lost by evaporation. Samples from all four mist chambers were composited daily and frozen in $35-40 \mathrm{~mL}$ (experiment-sized) aliquots. Field water blanks were collected concurrently from the same water supply, transported, and stored with the samples. Total organic carbon (TOC) concentrations ranged from 45 to $180 \mu \mathrm{M}-\mathrm{C}$ (Supplement Table S1). At the beginning of the study, mist chambers were baked at $500^{\circ} \mathrm{C}$ for $4 \mathrm{~h}$. Prior to and at the end of a sampling day, each mist chamber was cleaned using a 5 min deionized (DI) water wash step.

Based on daily forecast predictions, certain days were selected for intensive sampling (Table S1). Intensive sampling during SOAS was conducted on days when high levels of isoprene, sulfate, and $\mathrm{NO}_{x}$ were predicted by the National Center for Atmospheric Research (NCAR) using the FLEXible PARTicle dispersion model (FLEXPART) (Stohl et al., 2005) and the Model for Ozone and Related Chemical Tracers (MOZART) (Emmons et al., 2010). In general, mist chamber samples on intensive sampling days had higher organic content (TOC $=92-179 \mu \mathrm{M}-\mathrm{C}$ ), and hence we focused our experiments on those days and included two additional days from the non-intensive period that had high TOC values (Table 1).

\subsection{Aqueous $\mathrm{OH}$ radical oxidation in a cuvette chamber}

Ambient SOAS field samples were exposed to $\mathrm{OH}$ radicals in a custom-built photochemical temperature-controlled $\left(25^{\circ} \mathrm{C}\right)$ quartz cuvette reaction chamber. Ten screw-capped quartz cuvettes (Spectrocell Inc., Oreland, PA) containing $3 \mathrm{~mL}$ of sample were placed equidistant around a $254 \mathrm{~nm}$ mercury lamp (Heraeus Noblelight, Inc. Duluth, GA) housed in a quartz sheath (Ace Glass Inc., Vineland, NJ). A solar spectrum lamp was not used because the objective was to produce $\mathrm{OH}$ radicals by $\mathrm{H}_{2} \mathrm{O}_{2}$ photolysis, rather than to mimic tropospheric photolysis. The chamber was protected from ambient light by covering in aluminum foil. $\mathrm{OH}$ radicals $\left(1.25 \times 10^{-2} \mu \mathrm{M}[\mathrm{OH}] \mathrm{s}^{-1}\right)$ were generated in situ by photolysis of $125 \mu \mathrm{M} \mathrm{H}_{2} \mathrm{O}_{2}$, added to each cuvette prior to inserting the lamp. While we can calculate the $\mathrm{OH}$ production rate from hydrogen peroxide photolysis $\left(1.25 \times 10^{-2} \mu \mathrm{M}\right.$ $[\mathrm{OH}] \mathrm{s}^{-1}$ ), the concentration of $\mathrm{OH}$ in the reaction vessel depends also on the reactivity of the organics. If the WSOG mix behaves similarly to glyoxal, $\mathrm{OH}$ concentrations would be on the order of $10^{-12} \mathrm{M}$ (similar to (Tan et al., 2009). Cuvettes were removed at $t=10,20,30,40,60,80,100,120$, and $150 \mathrm{~min}$, and any remaining $\mathrm{H}_{2} \mathrm{O}_{2}$ was destroyed by addition of $36 \mu \mathrm{L}$ of $1 \%$ catalase (Sigma; 40200 units $\mathrm{mg}^{-1}$ ). A duplicate cuvette was removed at $t=40 \mathrm{~min}$ to calculate method precision. The following control experiments were performed: (1) sample $+\mathrm{H}_{2} \mathrm{O}_{2}$, (2) sample $+\mathrm{UV}$, (3) $\mathrm{H}_{2} \mathrm{O}_{2}+\mathrm{UV}$, and (4) field water blank $+\mathrm{OH}$. Replicate experiments were performed on selected samples. Ambient conditions for sample collection are given in Table 1 for samples used in experiments.

\subsection{Analytical methods}

Samples and field water blanks from all collection days were characterized by TOC analysis (Shimadzu 5000A) and electrospray ionization mass spectrometry (ESI-MS; HP Agilent 1100). IC (Dionex ICS 3000) was used to analyze organic anions and track the formation of products and intermediates. Samples at each reaction time were analyzed by ESI-MS in positive and negative ion modes to identify precursors and products. Selected samples were also analyzed by ultra-high-resolution electrospray ionization Fourier-transform ion cyclotron resonance mass spectrometry (ESI-FT-ICR-MS) and tandem MS (MS-MS) on a Thermo-Finnigan LTQ-XL at Woods Hole Oceanographic Institute, MA, to determine elemental composition and extract structural information on precursors. Analytical details and quality control measures have been described previously (Perri et al., 2009). Briefly, the ESI quadrupole mass spectrometer was operated in positive and negative ion modes over a mass range of 50-1000 amu. In the negative ion mode, the mobile phase consisted of $1: 1$ methanol to $0.05 \%$ formic acid in water; in the positive ion mode, it consisted of $0.05 \%$ formic acid in water. The fragmentor and capillary voltages for the ESI-MS were set at 40 and $3000 \mathrm{~V}$ (nitrogen drying gas; $10 \mathrm{~L} \mathrm{~min}^{-1} ; 350{ }^{\circ} \mathrm{C}$ ), respectively. Nitrobenzoic acid in the negative ion mode and caffeine in the positive ion mode were used as mass calibrants. Standard mixtures were analyzed with each experimental sequence: acetic acid, pyruvic acid, nitric acid, succinic acid, tartaric acid, ammonium sulfate, and oxalic acid in the negative ion mode and glyoxal, methylglyoxal, and glycolaldehyde in the positive ion mode.

ESI ionization efficiency varies with sample mix and over time. However, the mass spectra of the mist chamber samples 
Table 1. Sample collection dates for which experiments were run and their sampling conditions. Temperature, relative humidity, and ozone ranges are shown both for the entire day and collection time period. Total organic carbon (TOC) accuracy and precision are verified with potassium hydrogen phthalate (KHP) standards to be better than $5 \%$ (Perri et al., 2009).

\begin{tabular}{|c|c|c|c|c|c|}
\hline $\begin{array}{l}\text { Collection } \\
\text { date }\end{array}$ & $\begin{array}{l}\text { Collection } \\
\text { time }\end{array}$ & $\mu \mathrm{M}$ ТOC & $\begin{array}{r}T\left({ }^{\circ} \mathrm{C}\right) \\
\text { all day } \\
\text { (coll. time) }\end{array}$ & $\begin{array}{r}\mathrm{RH}(\%) \\
\text { all day } \\
\text { (coll. time) }\end{array}$ & $\begin{array}{r}\mathrm{O}_{3} \text { (ppbv) } \\
\text { all day } \\
\text { (coll. time) }\end{array}$ \\
\hline 11 Jun 2013 & $7.00 \mathrm{am}-7.00 \mathrm{pm}$ & 139.5 & $\begin{array}{r}22-32 \\
(23-32)\end{array}$ & $\begin{array}{r}53-99 \\
(53-98)\end{array}$ & $\begin{array}{r}9.9-38.2 \\
(11.3-38.2)\end{array}$ \\
\hline 12 Jun 2013 & $7.00 \mathrm{am}-7.00 \mathrm{pm}$ & 179.7 & $\begin{array}{r}23-33 \\
(23-33)\end{array}$ & $\begin{array}{r}48-94 \\
(48-94)\end{array}$ & $\begin{array}{r}13.1-41.8 \\
(13.1-41.8)\end{array}$ \\
\hline 15 Jun 2013 & $7.00 \mathrm{am}-7.00 \mathrm{pm}$ & 117.0 & $\begin{array}{r}17-31 \\
(18-31)\end{array}$ & $\begin{array}{r}45-94 \\
(45-90)\end{array}$ & $\begin{array}{r}11.6-53.4 \\
(11.6-53.4)\end{array}$ \\
\hline 16 Jun 2013 & $7.00 \mathrm{am}-7.00 \mathrm{pm}$ & 108.2 & $\begin{array}{r}22-32 \\
(22-32)\end{array}$ & $\begin{array}{r}53-93 \\
(53-84)\end{array}$ & $\begin{array}{r}2.6-41.7 \\
(23.1-41.7)\end{array}$ \\
\hline 20 Jun 2013 & $8.00 \mathrm{am}-5.00 \mathrm{pm}$ & 131.5 & $\begin{array}{r}20-30 \\
(21-30)\end{array}$ & $\begin{array}{r}55-98 \\
(59-94)\end{array}$ & $\begin{array}{r}4.8-52.2 \\
(6.2-42.8)\end{array}$ \\
\hline 21 Jun 2013 & $10.00 \mathrm{am}-6.00 \mathrm{pm}$ & 104.4 & $\begin{array}{r}20-30 \\
(25-30)\end{array}$ & $\begin{array}{r}50-93 \\
(50-78)\end{array}$ & $\begin{array}{r}16.6-45.2 \\
(30.3-45.2)\end{array}$ \\
\hline 29 Jun 2013 & $7.00 \mathrm{am}-7.00 \mathrm{pm}$ & 92.0 & $\begin{array}{r}21-31 \\
(22-31)\end{array}$ & $\begin{array}{r}43-100 \\
(43-100)\end{array}$ & $\begin{array}{r}16.3-53.7 \\
(16.3-53.7)\end{array}$ \\
\hline 30 Jun 2013 & $7.00 \mathrm{am}-7.00 \mathrm{pm}$ & 98.7 & $\begin{array}{r}20-30 \\
(20-30)\end{array}$ & $\begin{array}{r}38-100 \\
(38-100)\end{array}$ & $\begin{array}{r}1-53.5 \\
(1-53.5)\end{array}$ \\
\hline
\end{tabular}

were similar across experimental days, and the variability in the glyoxal, methylglyoxal, and glycolaldehyde standard ESI signals were $4-7 \%$ across analysis days, suggesting that ion abundance trends (Fig. S1-S2 in the Supplement) will reflect concentration trends. Six injections were averaged for each sample, and data were retained for each ion abundance greater than 0 within $95 \%$ confidence intervals. Ions were considered to be above detection limits when peaks were greater than the average plus 3 standard deviations of the water blank.

Organic acids were measured by IC (IonPac AS11-HC column; $30^{\circ} \mathrm{C}$, AG11-HC guard column) with conductivity detection $\left(35^{\circ} \mathrm{C}\right)$, using a Milli-Q water eluent and the potassium hydroxide $(\mathrm{KOH})$ gradient method. For oxalate, the method precision is $22 \%$, calculated as a pooled coefficient of variation (CV) from pairs of cuvettes removed at $t=40 \mathrm{~min}$. The analytical precision for oxalate is $19 \%$ (pooled CV) based on replicate analysis of $30 \%$ of samples. Analytical accuracy for oxalate is $7 \%$. The limit of detection (LOD) for oxalate by this protocol has been previously determined to be $0.1 \mu \mathrm{M}$ (Perri et al., 2009).

Samples from 15 and 30 June 2013 were analyzed using ultra-high-resolution FT-ICR-MS in the positive ion mode using 1:1 methanol and water as the mobile phase at $4 \mu \mathrm{L} \mathrm{min}^{-1}$, capillary temperature of $260^{\circ} \mathrm{C}$, and $3.8-$ $4.2 \mathrm{kV}$ spray voltage. Weekly analysis of standards (caffeine, peptide MRFA, Ultramark, sodium dodecyl sulfate (SDS), and sodium taurocholate) verified the mass accuracy $<2 \mathrm{ppm}$. Previously pyruvic acid and peroxyhemiacetal standards analyzed with the same protocol were within
2-10 ppm. Five precursor masses were isolated (isolation width: $m / z=2$ ) and fragmented by collision-induced dissociation (CID) (normalized collision energy: 26-33\%) with helium in the ion trap (IT) and infrared multiphoton dissociation (IRMPD) with a $\mathrm{CO}_{2}$ laser. Elemental composition (within $\pm 1 \mathrm{ppm}$ ) and double-bond equivalents of ions were calculated by the Midas Molecular Formula Calculator (v1.1). No restrictions were placed on the number of carbon, hydrogen, oxygen, nitrogen, sodium, and sulfur atoms included in the molecular formula calculations.

Compounds are detected in the ESI-MS by forming cluster ions with hydrogen, sodium, or ammonium in the positive ion mode; compounds are sometimes hydrated with water or methanol. In the negative ion mode, ions are deprotonated.

\section{Results and discussion}

$\mathrm{OH}$ oxidation experiments at concentrations relevant to cloud/fog water were conducted on samples collected on 11, 12, 15, 16, 20, 21, 29, and 30 June 2013, days on which TOC was highest, ranging from 92 to $179 \mu \mathrm{M}-\mathrm{C}$ in samples.

\subsection{Precursors in SOAS samples}

The concentration dynamics in experiments conducted with the eight daily composites were similar. Positive ions at $\mathrm{m} / \mathrm{z}$ $125,129,143,173$, and 187 exhibited reactant-like trends (Fig. 1; 30 June sample $+\mathrm{OH}$ ), showing decreasing signal intensity with increasing exposure to $\mathrm{OH}$. These ions disappeared after $40 \mathrm{~min}$ of oxidation. Together, these ions ac- 


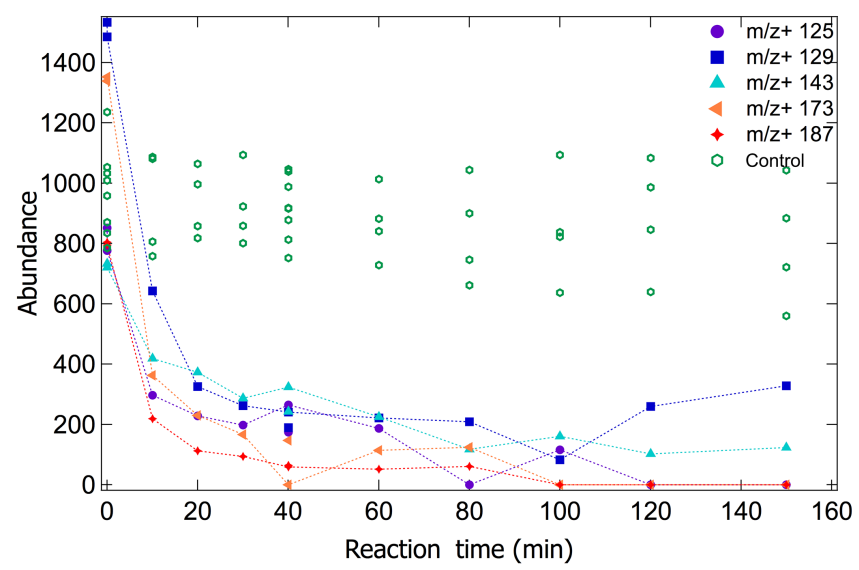

Figure 1. Positive ions (ESI-MS) exhibiting precursor-like trends during aqueous $\mathrm{OH}$ radical oxidation experiments with the ambient mixtures collected on 30 June. All days show similar trends, with all 5 reactant masses showing statistically significant decreasing trends as compared to the control experiments. Controls (sample $+\mathrm{UV}$, sample $+\mathrm{H}_{2} \mathrm{O}_{2}$ ) shown for $m / z$ 187; other masses show similar trends.

count for roughly $30 \%$ of the total ion current in the positive mode in the experiment samples. In control experiments, the abundance of these ions did not change over time, as illustrated in Fig. 1 (sample $+\mathrm{UV}$ and sample $+\mathrm{H}_{2} \mathrm{O}_{2}$ ) for the positive ion at $m / z \quad 187$ in samples collected on 15 and 30 June. Hence, reaction with $\mathrm{UV}$ or $\mathrm{H}_{2} \mathrm{O}_{2}$ alone does not explain the decreasing signals in the presence of $\mathrm{OH}$ radicals. In control experiments where we generated $\mathrm{OH}$ radicals in field water blanks, these ions were not observed, confirming that they are not contaminants from the water source. Experiments conducted on all sample days showed the same reactants decreasing with exposure to $\mathrm{OH}$, indicating that the water-soluble organics captured from the ambient daytime air in the mist chambers varied little across the study.

Elemental formulae assigned to precursor ions by Midas with corresponding MS-MS fragmentation data for the ions from 15 and 30 June samples are shown in Table 2. Both sampling days showed similar fragmentation spectra, consistent with the presence of the same parent compounds on both days, despite potential differences in the air mass on these days. MS-MS spectra were not obtained under the acquisition conditions of this work for positive ions at $m / z$ 143, 129, and 125. Proposed structures for the positive ions at $m / z 187$ and 173 based on MS-MS data are shown in Figs. 2 and 3. The $\mathrm{O} / \mathrm{C}$ ratio for the reactant masses range from 0.1 to 0.8 . In the following sections, we discuss individual reactants observed by ESI-MS. The discussion below is focused on the molecular formulas, rather than the detected ions, i.e., the parent compounds with $\mathrm{Na}^{+}$or $\mathrm{H}^{+}$.

$\mathrm{m} / \mathrm{z}$ 187: this is the ion with the highest $\mathrm{m} / \mathrm{z}$ observed by ESI-MS in the positive ion mode that follows a precursorlike trend (Figs. 1 and 2). The composition $\mathrm{C}_{7} \mathrm{H}_{16} \mathrm{O}_{4} \mathrm{Na}$ is

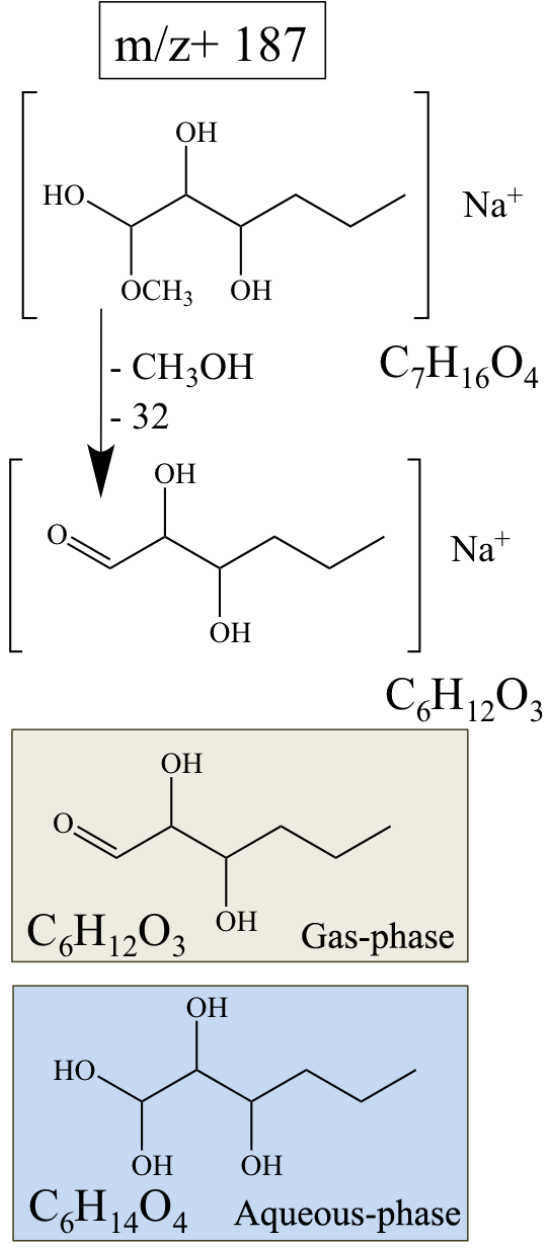

Figure 2. Proposed structure for the positive ion at $m / z$ 187. The top structure is the parent compound detected as a reactant in the ESI-MS; the following structures show the MS-MS fragments. This compound would take the forms shown in the shaded boxes if present in atmospheric air and water.

assigned by the Midas Molecular Formula Calculator based on the exact mass 187.0942 from FT-ICR MS, corresponding to the composition $\mathrm{C}_{7} \mathrm{H}_{16} \mathrm{O}_{4}$ for the neutral compound. The MS-MS shows loss of methanol, to give a product ion at $m / z 155.0680$, corresponding to the neutral molecular formula, $\mathrm{C}_{6} \mathrm{H}_{12} \mathrm{O}_{3}$, consistent with expectations for a sodium ion complex of a dihydroxy hemiacetal in methanol solution, shown in Fig. 2. In the absence of methanol, this compound would appear hydrated with water as the $\mathrm{C}_{6} \mathrm{H}_{14} \mathrm{O}_{4}$ tetrol, as shown in the blue box in Fig. 2. The corresponding gas-phase compound is shown in the tan box in Fig. 2.

$E$-2-hexenal and Z-3-hexenal are unsaturated aldehydes that have frequently been detected during field studies and are emitted to the atmosphere from vegetation due to leaf wounding (O'Connor et al., 2006). The gas-phase oxidation of these two green-leaf volatiles, as shown in Fig. 4a and b, 
Table 2. Elemental formulas assigned to precursor ions using ESI-FT-ICR MS in the positive ionization mode and Midas Molecular Formula Calculator. MS-MS fragmentation data are also shown.

\begin{tabular}{|c|c|c|c|c|}
\hline $\begin{array}{l}\text { Precursor } \\
\text { peak using } \\
\text { ESI-MS }\end{array}$ & $\begin{array}{r}\text { Positive mode } \\
m / z \text { (using } \\
\text { FT-ICR) }\end{array}$ & $\begin{array}{l}{[\mathrm{M}+\mathrm{Na}]^{+} \text {or }} \\
{[\mathrm{M}+\mathrm{H}]^{+}}\end{array}$ & Mol. wt. & $\begin{array}{l}\text { Double-bond } \\
\text { equivalents }\end{array}$ \\
\hline \multirow[t]{2}{*}{187} & 187.0942 & $\mathrm{C}_{7} \mathrm{H}_{16} \mathrm{O}_{4} \mathrm{Na}$ & 164.1043 & 0 \\
\hline & 155.0680 & $\mathrm{C}_{6} \mathrm{H}_{12} \mathrm{O}_{3} \mathrm{Na}$ & 132.0786 & 1 \\
\hline \multirow[t]{3}{*}{173} & 173.0782 & $\mathrm{C}_{6} \mathrm{H}_{14} \mathrm{O}_{4} \mathrm{Na}$ & 150.0887 & 0 \\
\hline & 141.0523 & $\mathrm{C}_{5} \mathrm{H}_{10} \mathrm{O}_{3} \mathrm{Na}$ & 118.0625 & 1 \\
\hline & 129.0524 & $\mathrm{C}_{4} \mathrm{H}_{10} \mathrm{O}_{3} \mathrm{Na}$ & 106.0625 & 0 \\
\hline 143 & 143.0676 & $\mathrm{C}_{5} \mathrm{H}_{12} \mathrm{O}_{3} \mathrm{Na}$ & 120.0781 & 0 \\
\hline 129 & 129.0520 & $\mathrm{C}_{4} \mathrm{H}_{10} \mathrm{O}_{3} \mathrm{Na}$ & 106.0625 & 0 \\
\hline 125 & 125.096 & $\mathrm{C}_{8} \mathrm{H}_{13} \mathrm{O}$ & 124.0883 & 3 \\
\hline
\end{tabular}

could explain the presence of $\mathrm{C}_{6} \mathrm{H}_{12} \mathrm{O}_{3}$ in the gas phase and $\mathrm{C}_{6} \mathrm{H}_{14} \mathrm{O}_{4}$ in the aqueous phase (Fig. 2).

$\mathrm{m} / \mathrm{z}$ 173: on most sampling days this reactant mass has the highest abundance in the positive mode ESI mass spectra (Supplement Fig. S1). Similar to other reactant peaks, it reacts away within the first 40 min of exposure to $\mathrm{OH}$ in the cuvette chamber (Fig. 1). The Midas-suggested molecular formula for this parent ion $(\mathrm{m} / \mathrm{z}$ 173.0782) and its two fragment ions at $m / z 141.0523$ and 129.0524 are $\mathrm{C}_{6} \mathrm{H}_{14} \mathrm{O}_{4}, \mathrm{C}_{5} \mathrm{H}_{10} \mathrm{O}_{3}$, and $\mathrm{C}_{4} \mathrm{H}_{10} \mathrm{O}_{3}$, respectively (a reactive parent ion with the formula $\mathrm{C}_{4} \mathrm{H}_{10} \mathrm{O}_{3}$ was also observed and is discussed below).

A likely structure for positive mode $m / z, 173$ is shown in Fig. 3. In this case the compound is proposed to be a $\mathrm{C}_{5} \mathrm{H}_{10} \mathrm{O}_{3}$ aldehyde in the gas phase (tan box in Fig. 3) and a $\mathrm{C}_{5} \mathrm{H}_{12} \mathrm{O}_{4}$ tetrol in water (blue box in Fig. 3). In the FTICR-MS it is seen hydrated with methanol. The parent ion at $m / z, 173$ loses methanol to form $\mathrm{C}_{5} \mathrm{H}_{10} \mathrm{O}_{3}(\mathrm{~m} / z$ 141.0523), and it also loses $\mathrm{C}_{2} \mathrm{H}_{4} \mathrm{O}$ to form $\mathrm{C}_{4} \mathrm{H}_{10} \mathrm{O}_{3}(\mathrm{~m} / z$ 129.0524). The aqueous oxidation precursor observed as $m / z 173$ and tentatively identified as the $\mathrm{C}_{5} \mathrm{H}_{10} \mathrm{O}_{3}$ aldehyde shown in tan in Fig. 3 could be derived from another green-leaf volatile. Specifically, $\mathrm{C}_{5} \mathrm{H}_{10} \mathrm{O}_{3}$ is consistent with the gas-phase oxidation product of $(E)$-2-methyl-2-butenal, another green-leaf volatile (Fig. 4c) (Jiménez et al., 2009; Lanza et al., 2008).

Positive ions at $\mathrm{m} / \mathrm{z}, 143,129$, and 125: no fragments were observed for these reactants under conditions of MS-MS acquisition in this work. The Midas-predicted molecular formulae for the ions at $m / z 143.0676,129.0520$, and 125.096 are $\mathrm{C}_{5} \mathrm{H}_{12} \mathrm{O}_{3}, \mathrm{C}_{4} \mathrm{H}_{10} \mathrm{O}_{3}$, and $\mathrm{C}_{8} \mathrm{H}_{12} \mathrm{O}$, respectively. Interestingly, the reactant detected at $m / z 129$ has the same mass as a fragment of the parent ion at $m / z 173$ discussed earlier (and the structure of the $\mathrm{C}_{4} \mathrm{H}_{10} \mathrm{O}_{3}$ fragment shown in Fig. 3 is a possible structure for $m / z 129$ ).

Methodological limitations: in this work, we aim to collect the ambient mix of water-soluble gases into water at concentrations comparable to those found in clouds and fogs with the purpose of simulating cloud/fog-relevant $\mathrm{OH}$ oxida- tion chemistry and identifying previously unrecognized precursors of aqueous chemistry. Below we discuss limitations with respect to our ability to collect and store these aqueous mixtures and with respect to our ability to identify the $\mathrm{OH}-$ reactive compounds collected.

Mist chamber collection times ( $4 \mathrm{~h})$ were selected with the aim of collecting ambient mixtures of water-soluble gases near Henry's law equilibrium. Two pieces of evidence suggest that gas-aqueous partitioning of the WSOGs is close to Henry's law equilibrium in our samples. In previous testing conducted at a different east coast location that is a recipient of long-range transport (i.e., central New Jersey), we found that WSOG concentrations in the mist chamber leveled off after 1-3 $\mathrm{h}$ of ambient sampling, suggesting that the collected WSOG mixture approaches Henry's law equilibrium over these collection times. This is consistent with the one measurement we have of breakthrough at SOAS, where we ran two mist chambers in series and found TOC concentrations within $\pm 11 \%$ of each other. These measurements suggest that a representative mixture of the water-soluble gases entering the mist chambers was collected.

However, WSOGs can be lost during sampling and storage through (1) losses in tubing and by adsorption to the QFF during collection; (2) reactions in the mist chamber during collection with water-soluble ambient oxidants capable of penetrating the inlet (e.g., ozone); and (3) losses during storage post collection. The QFF removes particles upstream of the mist chambers. In the early stages of sampling, on the clean filter, adsorption of gases on the filter will reduce the concentrations of gases sampled by the mist chamber until these gases reach gas-phase-adsorbed-phase equilibrium. Using glyoxal as a WSOG surrogate and the work of Mader and Pankow (2001), we predict that the measured WSOG in the mist chamber will be depleted for less than $2 \%$ of our sampling time (after $<0.1 \mathrm{~m}^{3}$ ) due to loss to the filter. Thus, we expect water-soluble gases to penetrate through the QFF very efficiently for collection in the mist chamber wa- 


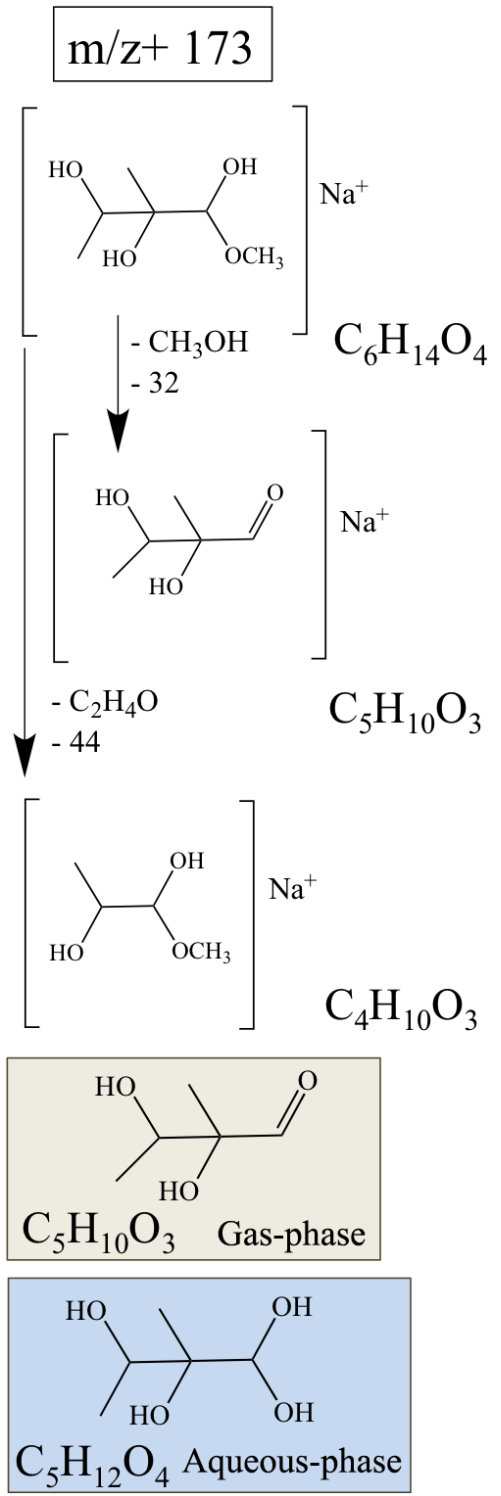

Figure 3. Proposed structure for the positive ion at $m / z$ 173. The top structures in each panel are the parent compound detected as a reactant in the ESI-MS; the following structures show the MSMS fragments. This compound would take the forms shown in the shaded boxes if present in atmospheric air and water.

ter. Losses to Teflon inlets and chamber walls (Krechmer et al., 2016) can be significant and variable and may reduce the number of species we are able to collect and identify in this work. While $\mathrm{OH}$ radicals are unlikely to penetrate the inlet, ozone might. Thus some ozone could be scrubbed by the mist chambers and could result in oxidation of some unsaturated WSOGs during collection.

Though many organics are stable when stored frozen in water, IEPOX does not survive extended storage in water (confirmed with our organic synthesis collaborator). We expect this to be the case for isoprene hydroxyhydroperoxide (a)<smiles></smiles>

(b)<smiles>CCC(O)C(O)CC=CCCC=CCC=O</smiles>

(c)<smiles></smiles>

Figure 4. Gas-phase oxidation of (a) E-2-hexenal, (b) Z-3-hexenal, and (c) (E)-2-methyl-2-butenal. The diols are proposed to result from hydrolysis of the corresponding epoxides, which may be generated by attack of $\mathrm{OH}$ followed by addition of $\mathrm{O}_{2}, 1,5-\mathrm{H}$ transfer, and elimination of $\mathrm{OH}$ (Crounse et al., 2012; Peeters et al., 2001) or by reaction with $\mathrm{RO}_{2}$. (Stark, 1997).

(ISOPOOH) also. ISOPOOH is an $\mathrm{OH}$ oxidation product of isoprene, which is further oxidized by $\mathrm{OH}$ under low-NO conditions to form isomeric IEPOX (Paulot et al., 2009). IEPOX and ISOPOOH were present in the gas phase during the SOAS campaign (Nguyen et al., 2015). They have relatively high Henry's law constants (i.e., $\mathrm{H}_{\mathrm{L}, \mathrm{IEPOX}}=2.7 \times$ $10^{6} \mathrm{M} \mathrm{atm}^{-1}$ ). IEPOX was readily detected in ambient samples spiked with 3000,300 , and $30 \mu \mathrm{M}$ of IEPOX, indicating that it can be ionized in our sample matrix. (Authentic trans$\beta$-IEPOX, which is the predominant isomer of IEPOX, was synthesized for this purpose; Zhang et al., 2012.) However, it was not found in our ambient samples since it is not stable when stored in water.

Together, the ions discussed herein account for $30 \%$ of the total ion abundance. The remaining $70 \%$ did not exhibit a clearly decreasing trend during $\mathrm{OH}$ oxidation experiments. The remaining $70 \%$ could represent compounds that are stable with respect to $\mathrm{OH}$ oxidation in water or that react too slowly to be observed under the experimental conditions used. However, it should be recognized that some watersoluble $\mathrm{OH}$-reactive compounds might not have been identifiable as reactive because they were intermediates of multiple precursors. We have observed this phenomenon previously in aqueous $\mathrm{OH}$ oxidation experiments conducted with mixed aldehyde standards (unpublished). In those experiments, several modest concentration increases and decreases were observed in experiments and model predictions for some intermediates. Together, these methodological limitations suggest 
that additional $\mathrm{OH}$-reactive water-soluble gases were likely present that we were unable to identify.

\subsection{Product formation during aqueous oxidation experiments}

Figure 5 shows significant formation of oxalate and pyruvate in $\mathrm{OH}$ radical experiments conducted with all samples but not during the control experiments (sample + UV; sample $+\mathrm{H}_{2} \mathrm{O}_{2}$ ). Pyruvate peaks around $60-80 \mathrm{~min}$, which is earlier than the oxalate peak at 100-120 min (Fig. 5). Acetate/glycolate (which co-elute in the IC) also forms in at least some samples and reacts away in the presence of $\mathrm{OH}$ (Fig. S3). Sulfate and nitrate concentrations remained constant throughout the experiment as measured by the IC. While there may be many sources of oxalate, aqueous $\mathrm{OH}$ radical oxidation of pyruvate in the aqueous phase is known to form oxalate at dilute (cloud-relevant) concentrations (Carlton et al., 2006). Aqueous acetate oxidation is also a source of oxalate (Tan et al., 2012). The concentration dynamics are consistent with a role for these compounds in the formation of oxalate in the ambient mixtures although the mechanisms by which pyruvate and acetate formed are not well constrained in these experiments. These observations suggest that oxalate, pyruvate, and acetate/glycolate can form in ambient mixtures of water-soluble gases in the southeastern US in the presence of clouds/fogs and oxidants. Pyruvate and oxalate have been observed primarily in the particle phase in the atmosphere (Saxena and Hildemann, 1996; Limbeck et al., 2001; Yao et al., 2002; Kawamura et al., 2003; Martinelango et al., 2007). Moreover, modeling studies of oxalate, the most abundant dicarboxylic acid in the atmosphere, suggest that aqueous chemistry is a large contributor of oxalate formation globally, making it a good tracer for $\mathrm{SOA}_{\mathrm{AQ}}$ formed in clouds and fogs (Myriokefalitakis et al., 2011). Above- versus below-cloud measurements also support this (Sorooshian et al., 2010). Thus, the experiments suggest that aqueous oxidation of ambient (southeastern US) water-soluble mixtures at cloud/fog-relevant concentrations has the potential to form material that remains in the particlephase species after droplet evaporation, i.e., $\mathrm{SOA}_{\mathrm{AQ}}$. However, the atmospheric prevalence of particle-phase oxalate can only be explained by the formation of salts and complexes, since oxalic acid is volatile and the volatility of oxalate salts is orders of magnitude lower than that of oxalic acid (Ortiz-Montalvo et al., 2014; Paciga et al., 2014). The aerosol at the SOAS ground site was acidic (campaign average $\mathrm{pH} \sim 0$.94) (Guo et al., 2015), and as a consequence oxalic acid may remain largely in the gas phase in this environment but may eventually react on more basic surfaces, e.g., coarse particles. Note that we expect the products of aqueous chemistry in wet aerosols to be different from those in clouds and fogs because of the extremely high (molar) solute concentrations in wet aerosols (Surratt et al., 2007; Noziere

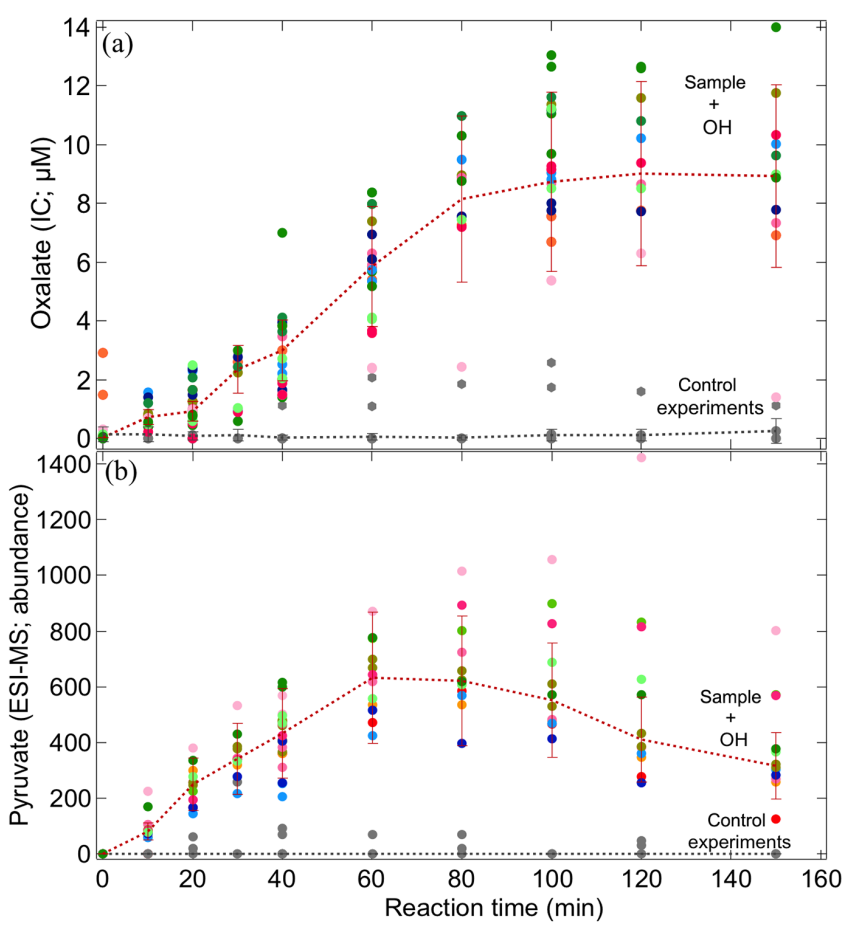

Figure 5. (a) Oxalate (by IC) for all $\mathrm{OH}$ radical oxidation experiments conducted with ambient samples (Table 1). (b) Abundance of the negative ion at $m / z 87$ (pyruvate) as observed in the ESI-MS when the ambient SOAS samples are exposed to $\mathrm{OH}$. Error bars represent the pooled coefficient of variation calculated across experimental days. Note that oxalate and pyruvate are formed in all samples in the presence, but not the absence, of $\mathrm{OH}$. Gray points represent control experiments (11 June sample + UV, 11 June sample $+\mathrm{H}_{2} \mathrm{O}_{2}$, 30 June field water blank $+\mathrm{OH}$ ).

et al., 2008; Galloway et al., 2009; Lim et al., 2010; Sareen et al., 2010; Nguyen et al., 2012).

\subsection{Atmospheric implications}

We have tentatively characterized several water-soluble $\mathrm{OH}-$ reactive species collected at an isoprene-rich photochemically active location in the southeastern US. In several cases compounds with the same elemental composition were measured in the gas phase by high-resolution time-of-flight chemical ionization mass spectrometry (HRToF-CIMS). The tentative structures for the proposed reactants are consistent with formation from green-leaf volatiles and isoprene oxidation. Aqueous $\mathrm{OH}$ oxidation under dilute conditions (TOC of ca. $100 \mu \mathrm{M}$ ) relevant to fogs and clouds produced oxalate and pyruvate, suggesting that cloud/fog processing of these compounds (and subsequent neutralization or complexation) is a potential source of SOA. The reactants characterized in this work are precursors for aqueous chemistry and are potentially important $\mathrm{SOA}_{\mathrm{AQ}}$ precursors in all atmospheric waters, i.e., clouds, fogs, and wet aerosols. The aqueous chem- 
istry of these precursors is poorly understood and warrants further study.

\section{Conclusions}

We observed formation of pyruvate, oxalate, and acetate/glycolate during $\mathrm{OH}$ oxidation experiments conducted with ambient mixtures of WSOG from the southeastern US. The formation of these highly oxygenated organic acids indicates a potential for $\mathrm{SOA}_{\mathrm{AQ}}$ formation (e.g., upon neutralization with $\mathrm{NH}_{3}$, metal complexation, or heterogeneous reaction on course dust/salt particles). Given the acidity of SOAS fine particles, we think it is unlikely that oxalate will be found in substantial quantities in the fine aerosol at the SOAS ground site.

We tentatively characterized several water-soluble reactive precursors which undergo aqueous chemistry and $\mathrm{SOA}_{\mathrm{AQ}}$ formation in wet aerosols, clouds, and fogs at this location. High-resolution mass spectrometric analyses suggest precursors had $\mathrm{O} / \mathrm{C}$ ranging from 0.125 to 0.80 , and some are tentatively gas-phase oxidation products of green-leaf volatiles. No distinct difference was seen in the aqueous oxidation of ambient samples collected across days during the SOAS field campaign. Further work involving organic synthesis, aqueous $\mathrm{OH}$ oxidation of authentic standards, and mass spectral analyses with pre-separation are likely to yield further insights into the aqueous chemistry of these compounds in the future.

\section{Data availability}

Included are sampling and TOC data for all collection days (Table S1); time series of ESI-MS abundances for $m / z 125$, 129, 143, 173, and 187 (Fig. S1); discussion and graphical comparisons with chemical ionization mass spectrometry (CIMS) (Fig. S2), and concentration dynamics for acetate/glycolate during aqueous $\mathrm{OH}$ experiments and control experiments (Fig. S3). The material is available free of charge via the Internet at http://pubs.acs.org.

\section{The Supplement related to this article is available online at doi:10.5194/acp-16-14409-2016-supplement.}

Acknowledgements. This research was funded by the EPA STAR grant no. 35412. The views expressed in this manuscript are those of the authors and do not necessarily reflect the views or policies of the US Environmental Protection Agency. The authors acknowledge Melissa Soule and funding sources of the WHOI FT-MS users' facility (NSF OCE-0619608 and the Gordon and Betty Moore Foundation). We also thank Jeffrey Kirland, Ronald Lauck, and Nancy Sazo for their invaluable assistance in the laboratory and field, and Louisa Emmons for the air quality forecasting during SOAS.

Edited by: M. C. Facchini

Reviewed by: two anonymous referees

\section{References}

Altieri, K. E., Carlton, A. G., Lim, H.-J., Turpin, B. J., and Seitzinger, S. P.: Evidence for Oligomer Formation in Clouds: Reactions of Isoprene Oxidation Products, Environ. Sci. Technol., 40, 4956-4960, 2006.

Anderson, C., Dibb, J. E., Griffin, R. J., and Bergin, M. H.: Simultaneous measurements of particulate and gas-phase water-soluble organic carbon concentrations at remote and urban-influenced locations, Geophys. Res. Lett., 35, L13706, doi:10.1029/2008GL033966, 2008a.

Anderson, C. H., Dibb, J. E., Griffin, R. J., Hagler, G. S. W., and Bergin, M. H.: Atmospheric water-soluble organic carbon measurements at Summit, Greenland, Atmos. Environ., 42, 56125621, 2008b.

Blando, J. D. and Turpin, B. J.: Secondary organic aerosol formation in cloud and fog droplets: a literature evaluation of plausibility, Atmos. Environ., 34, 1623-1632, 2000. 2008b.

Boris, A. J., Desyaterik, Y., and Collett, J. L.: How do components of real cloud water affect aqueous pyruvate oxidation?, Atmos. Res., 143, 95-106, 2014.

Carlton, A. G. and Turpin, B. J.: Particle partitioning potential of organic compounds is highest in the Eastern US and driven by anthropogenic water, Atmos. Chem. Phys., 13, 10203-10214, doi:10.5194/acp-13-10203-2013, 2013.

Carlton, A. G., Turpin, B. J., Lim, H. J., Altieri, K. E., and Seitzinger, S.: Link between isoprene and secondary organic aerosol (SOA): Pyruvic acid oxidation yields low volatility organic acids in clouds, Geophys. Res. Lett., 33, L06822, doi:10.1029/2005g1025374, 2006.

Carlton, A. G., Turpin, B. J., Altieri, K. E., Seitzinger, S. P., Mathur, R., Roselle, S. J., and Weber, R. J.: CMAQ Model Performance Enhanced When In-Cloud Secondary Organic Aerosol is Included: Comparisons of Organic Carbon Predictions with Measurements, Environ. Sci. Technol., 42, 8798-8802, 2008.

Crahan, K. K., Hegg, D., Covert, D. S., and Jonsson, H.: An exploration of aqueous oxalic acid production in the coastal marine atmosphere, Atmos. Environ., 38, 3757-3764, 2004.

Crounse, J. D., Knap, H. C., Ørnsø, K. B., Jørgensen, S., Paulot, F., Kjaergaard, H. G., and Wennberg, P. O.: Atmospheric Fate of Methacrolein, 1. Peroxy Radical Isomerization Following Addition of $\mathrm{OH}$ and $\mathrm{O}_{2}$, J. Phys. Chem. A, 116, 5756-5762, 2012.

De Haan, D. O., Corrigan, A. L., Smith, K. W., Stroik, D. R., Turley, J. J., Lee, F. E., Tolbert, M. A., Jimenez, J. L., Cordova, K. E., and Ferrell, G. R.: Secondary Organic Aerosol-Forming Reactions of Glyoxal with Amino Acids, Environ. Sci. Technol., 43, 28182824, 2009a.

De Haan, D. O., Tolbert, M. A., and Jimenez, J. L.: Atmospheric condensed-phase reactions of glyoxal with methylamine, Geophys. Res. Lett., 36, L11819, doi:10.1029/2009GL037441, 2009b. 
Dibb, J. E., Talbot, R. W., and Bergin, M. H.: Soluble acidic species in air and snow at Summit, Greenland, Geophys. Res. Lett., 21, 1627-1630, 1994.

Donahue, N. M., Robinson, A. L., Stanier, C. O., and Pandis, S. N.: Coupled Partitioning, Dilution, and Chemical Aging of Semivolatile Organics, Environ. Sci. Technol., 40, 2635-2643, 2006.

El Haddad, I., Yao, L., Nieto-Gligorovski, L., Michaud, V., Temime-Roussel, B., Quivet, E., Marchand, N., Sellegri, K., and Monod, A.: In-cloud processes of methacrolein under simulated conditions - Part 2: Formation of secondary organic aerosol, Atmos. Chem. Phys., 9, 5107-5117, doi:10.5194/acp-9-5107-2009, 2009.

Ervens, B., Feingold, G., Frost, G. J., and Kreidenweis, S. M.: A modeling study of aqueous production of dicarboxylic acids: 1. Chemical pathways and speciated organic mass production, J. Geophys. Res.-Atmos., 109, D15205, doi:10.1029/2003JD004387, 2004.

Ervens, B., Carlton, A. G., Turpin, B. J., Altieri, K. E., Kreidenweis, S. M., and Feingold, G.: Secondary organic aerosol yields from cloud-processing of isoprene oxidation products, Geophys. Res. Lett., 35, L02816, doi:10.1029/2007GL031828, 2008.

Ervens, B., Turpin, B. J., and Weber, R. J.: Secondary organic aerosol formation in cloud droplets and aqueous particles (aqSOA): a review of laboratory, field and model studies, Atmos. Chem. Phys., 11, 11069-11102, doi:10.5194/acp-1111069-2011, 2011.

Ervens, B., Wang, Y., Eagar, J., Leaitch, W. R., Macdonald, A. M., Valsaraj, K. T., and Herckes, P.: Dissolved organic carbon (DOC) and select aldehydes in cloud and fog water: the role of the aqueous phase in impacting trace gas budgets, Atmos. Chem. Phys., 13, 5117-5135, doi:10.5194/acp-13-5117-2013, 2013.

Foley, K. M., Roselle, S. J., Appel, K. W., Bhave, P. V., Pleim, J. E., Otte, T. L., Mathur, R., Sarwar, G., Young, J. O., Gilliam, R. C., Nolte, C. G., Kelly, J. T., Gilliland, A. B., and Bash, J. O.: Incremental testing of the Community Multiscale Air Quality (CMAQ) modeling system version 4.7, Geosci. Model Dev., 3, 205-226, 1doi:0.5194/gmd-3-205-2010, 2010.

Fu, T.-M., Jacob, D. J., Wittrock, F., Burrows, J. P., Vrekoussis, M., and Henze, D. K.: Global budgets of atmospheric glyoxal and methylglyoxal, and implications for formation of secondary organic aerosols, J. Geophys. Res.-Atmos., 113, D15303, doi:10.1029/2007JD009505, 2008.

Fu, T.-M., Jacob, D. J., and Heald, C. L.: Aqueous-phase reactive uptake of dicarbonyls as a source of organic aerosol over eastern North America, Atmos. Environ., 43, 1814-1822, 2009.

Galloway, M. M., Chhabra, P. S., Chan, A. W. H., Surratt, J. D., Flagan, R. C., Seinfeld, J. H., and Keutsch, F. N.: Glyoxal uptake on ammonium sulphate seed aerosol: reaction products and reversibility of uptake under dark and irradiated conditions, Atmos. Chem. Phys., 9, 3331-3345, doi:10.5194/acp-9-3331-2009, 2009.

Gaston, C. J., Thornton, J. A., and Ng, N. L.: Reactive uptake of $\mathrm{N} 2 \mathrm{O} 5$ to internally mixed inorganic and organic particles: the role of organic carbon oxidation state and inferred organic phase separations, Atmos. Chem. Phys., 14, 5693-5707, doi:10.5194/acp-14-5693-2014, 2014.

Goldstein, A. H., Koven, C. D., Heald, C. L., and Fung, I. Y.: Biogenic carbon and anthropogenic pollutants combine to form a cooling haze over the southeastern United States, P. Natl. Acad. Sci. USA, 106, 8835-8840, 2009.

Gong, W., Stroud, C., and Zhang, L.: Cloud Processing of Gases and Aerosols in Air Quality Modeling, Atmosphere, 2, 567-616, 2011.

Guo, H., Xu, L., Bougiatioti, A., Cerully, K. M., Capps, S. L., Hite Jr, J. R., Carlton, A. G., Lee, S. H., Bergin, M. H., Ng, N. L., Nenes, A., and Weber, R. J.: Fine-particle water and $\mathrm{pH}$ in the southeastern United States, Atmos. Chem. Phys., 15, 5211-5228, doi:10.5194/acp-15-5211-2015, 2015.

Hallquist, M., Wenger, J. C., Baltensperger, U., Rudich, Y., Simpson, D., Claeys, M., Dommen, J., Donahue, N. M., George, C., Goldstein, A. H., Hamilton, J. F., Herrmann, H., Hoffmann, T., Iinuma, Y., Jang, M., Jenkin, M. E., Jimenez, J. L., KiendlerScharr, A., Maenhaut, W., McFiggans, G., Mentel, T. F., Monod, A., Prévôt, A. S. H., Seinfeld, J. H., Surratt, J. D., Szmigielski, R., and Wildt, J.: The formation, properties and impact of secondary organic aerosol: current and emerging issues, Atmos. Chem. Phys., 9, 5155-5236, doi:10.5194/acp-9-5155-2009, 2009.

He, C., Liu, J., Carlton, A. G., Fan, S., Horowitz, L. W., Levy Ii, H., and Tao, S.: Evaluation of factors controlling global secondary organic aerosol production from cloud processes, Atmos. Chem. Phys., 13, 1913-1926, doi:10.5194/acp-13-1913-2013, 2013.

Heald, C. L., Jacob, D. J., Turquety, S., Hudman, R. C., Weber, R. J., Sullivan, A. P., Peltier, R. E., Atlas, E. L., de Gouw, J. A., Warneke, C., Holloway, J. S., Neuman, J. A., Flocke, F. M., and Seinfeld, J. H.: Concentrations and sources of organic carbon aerosols in the free troposphere over North America, J. Geophys. Res.-Atmos., 111, D23S47, doi:10.1029/2006JD007705, 2006.

Hennigan, C. J., Bergin, M. H., Russell, A. G., Nenes, A., and Weber, R. J.: Gas/particle partitioning of water-soluble organic aerosol in Atlanta, Atmos. Chem. Phys., 9, 3613-3628, doi:10.5194/acp-9-3613-2009, 2009.

Herrmann, H., Tilgner, A., Barzaghi, P., Majdik, Z., Gligorovski, S., Poulain, L., and Monod, A.: Towards a more detailed description of tropospheric aqueous phase organic chemistry: CAPRAM 3.0, Atmos. Environ., 39, 4351-4363, 2005.

Jiménez, E., Lanza, B., Antiñolo, M., and Albaladejo, J.: Influence of temperature on the chemical removal of 3-methylbutanal, trans-2-methyl-2-butenal, and 3-methyl-2-butenal by $\mathrm{OH}$ radicals in the troposphere, Atmos. Environ., 43, 4043-4049, 2009.

Kalberer, M., Paulsen, D., Sax, M., Steinbacher, M., Dommen, J., Prevot, A. S. H., Fisseha, R., Weingartner, E., Frankevich, V., Zenobi, R., and Baltensperger, U.: Identification of Polymers as Major Components of Atmospheric Organic Aerosols, Science, 303, 1659-1662, 2004.

Kawamura, K. and Ikushima, K.: Seasonal changes in the distribution of dicarboxylic acids in the urban atmosphere, Environ. Sci. Technol., 27, 2227-2235, 1993.

Kawamura, K., Kasukabe, H., and Barrie, L. A.: Source and reaction pathways of dicarboxylic acids, ketoacids and dicarbonyls in arctic aerosols: One year of observations, Atmos. Environ., 30, 1709-1722, 1996.

Kawamura, K., Umemoto, N., Mochida, M., Bertram, T., Howell, S., and Huebert, B. J.: Water-soluble dicarboxylic acids in the tropospheric aerosols collected over east Asia and western North Pacific by ACE-Asia C-130 aircraft, J. Geophys. Re.-Atmos., 108, 8639, doi:10.1029/2002JD003256, 2003. 
Krechmer, J. E., Pagonis, D., Ziemann, P. J., and Jimenez, J. L.: Quantification of Gas-Wall Partitioning in Teflon Environmental Chambers Using Rapid Bursts of Low-Volatility Oxidized Species Generated in Situ, Environ. Sci. Technol., 50, 57575765, 2016.

Kroll, J. H., Ng, N. L., Murphy, S. M., Varutbangkul, V., Flagan, R. C., and Seinfeld, J. H.: Chamber studies of secondary organic aerosol growth by reactive uptake of simple carbonyl compounds, J. Geophys. Res., 110, D23207, doi:10.1029/2005JD006004, 2005.

Lanza, B., Jiménez, E., Ballesteros, B., and Albaladejo, J.: Absorption cross section determination of biogenic $\mathrm{C} 5$-aldehydes in the actinic region, Chem. Phys. Lett., 454, 184-189, 2008.

Lee, A. K. Y., Zhao, R., Gao, S. S., and Abbatt, J. P. D.: AqueousPhase OH Oxidation of Glyoxal: Application of a Novel Analytical Approach Employing Aerosol Mass Spectrometry and Complementary Off-Line Techniques, J. Phys. Chem. A, 115, 1051710526, 2011.

Lee, A. K. Y., Hayden, K. L., Herckes, P., Leaitch, W. R., Liggio, J., Macdonald, A. M., and Abbatt, J. P. D.: Characterization of aerosol and cloud water at a mountain site during WACS 2010: secondary organic aerosol formation through oxidative cloud processing, Atmos. Chem. Phys., 12, 7103-7116, doi:10.5194/acp-12-7103-2012, 2012.

Liggio, J., Li, S. M., and McLaren, R.: Heterogeneous reactions of glyoxal on particulate matter: Identification of acetals and sulfate esters, Environ. Sci. Technol., 39, 1532-1541, 2005.

Lim, H.-J., Carlton, A. G., and Turpin, B. J.: Isoprene Forms Secondary Organic Aerosol through Cloud Processing: Model Simulations, Environ. Sci. Technol., 39, 4441-4446, 2005.

Lim, Y. B., Tan, Y., Perri, M. J., Seitzinger, S. P., and Turpin, B. J.: Aqueous chemistry and its role in secondary organic aerosol (SOA) formation, Atmos. Chem. Phys., 10, 1052110539, doi:10.5194/acp-10-10521-2010, 2010.

Limbeck, A., Puxbaum, H., Otter, L., and Scholes, M. C.: Semivolatile behavior of dicarboxylic acids and other polar organic species at a rural background site (Nylsvley, RSA), Atmos. Environ., 35, 1853-1862, 2001.

Lin, G., Sillman, S., Penner, J. E., and Ito, A.: Global modeling of SOA: the use of different mechanisms for aqueous-phase formation, Atmos. Chem. Phys., 14, 5451-5475, doi:10.5194/acp-145451-2014, 2014.

Lin, P., Huang, X.-F., He, L.-Y., and Zhen Yu, J.: Abundance and size distribution of HULIS in ambient aerosols at a rural site in South China, J. Aerosol Sci., 41, 74-87, 2010.

Liu, J., Horowitz, L. W., Fan, S., Carlton, A. G., and Levy, H.: Global in-cloud production of secondary organic aerosols: Implementation of a detailed chemical mechanism in the GFDL atmospheric model AM3, J. Geophys. Re.-Atmos., 117, D15303, doi:10.1029/2012JD017838, 2012.

Loeffler, K. W., Koehler, C. A., Paul, N. M., and De Haan, D. O.: Oligomer formation in evaporating aqueous glyoxal and methyl glyoxal solutions, Environ. Sci. Technol., 40, 6318-6323, 2006.

Mader, B. T. and Pankow, J. F.: Gas/Solid Partitioning of Semivolatile Organic Compounds (SOCs) to Air Filters, 3. An Analysis of Gas Adsorption Artifacts in Measurements of Atmospheric SOCs and Organic Carbon (OC) When Using Teflon Membrane Filters and Quartz Fiber Filters, Environ. Sci. Technol., 35, 3422-3432, 2001.
Martinelango, P. K., Dasgupta, P. K., and Al-Horr, R. S.: Atmospheric production of oxalic acid/oxalate and nitric acid/nitrate in the Tampa Bay airshed: Parallel pathways, Atmos. Environ., 41, 4258-4269, 2007.

Monge, M. E., Rosenørn, T., Favez, O., Müller, M., Adler, G., Abo Riziq, A., Rudich, Y., Herrmann, H., George, C., and D’Anna, B.: Alternative pathway for atmospheric particles growth, P. Natl. Acad. Sci. USA, 109, 6840-6844, 2012.

Myriokefalitakis, S., Tsigaridis, K., Mihalopoulos, N., Sciare, J., Nenes, A., Kawamura, K., Segers, A., and Kanakidou, M.: Incloud oxalate formation in the global troposphere: a 3-D modeling study, Atmos. Chem. Phys., 11, 5761-5782, doi:10.5194/acp11-5761-2011, 2011.

Nguyen, T. B., Lee, P. B., Updyke, K. M., Bones, D. L., Laskin, J., Laskin, A., and Nizkorodov, S. A.: Formation of nitrogenand sulfur-containing light-absorbing compounds accelerated by evaporation of water from secondary organic aerosols, J. Geophys. Re.-Atmos., 117, D01207, doi:10.1029/2011JD016944, 2012.

Nguyen, T. B., Crounse, J. D., Teng, A. P., St. Clair, J. M., Paulot, F., Wolfe, G. M., and Wennberg, P. O.: Rapid deposition of oxidized biogenic compounds to a temperate forest, P. Natl. Acad. Sci. USA, 112, E392-E401, 2015.

Nguyen, T. K. V., Petters, M. D., Suda, S. R., Guo, H., Weber, R. J., and Carlton, A. G.: Trends in particle-phase liquid water during the Southern Oxidant and Aerosol Study, Atmos. Chem. Phys., 14, 10911-10930, doi:10.5194/acp-14-10911-2014, 2014.

Nozière, B. and Cordova, A.: A kinetic and mechanistic study of the amino acid catalyzed aldol condensation of acetaldehyde in aqueous and salt solutions, J. Phys. Chem. A, 112, 2827-2837, 2008.

Noziere, B., Dziedzic, P., and Córdova, A.: Products and kinetics of the liquid-phase reaction of glyoxal catalyzed by ammonium ions (NH4+), J. Phys. Chem. A, 113, 231-237, 2008.

Nozière, B., Ekström, S., Alsberg, T., and Holmström, S.: Radical-initiated formation of organosulfates and surfactants in atmospheric aerosols, Geophys. Res. Lett., 37, L05806, doi:10.1029/2009GL041683, 2010.

O'Connor, M. P., Wenger, J. C., Mellouki, A., Wirtz, K., and Munoz, A.: The atmospheric photolysis of E-2-hexenal, Z-3hexenal and E,E-2,4-hexadienal, Phys. Chem. Chem. Phys., 8, 5236-5246, 2006.

Odum, J. R., Hoffmann, T., Bowman, F., Collins, D., Flagan, R. C., and Seinfeld, J. H.: Gas/Particle Partitioning and Secondary Organic Aerosol Yields, Environ. Sci. Technol., 30, 2580-2585, 1996.

Ortiz-Montalvo, D. L., Häkkinen, S. A. K., Schwier, A. N., Lim, Y. B., McNeill, V. F., and Turpin, B. J.: Ammonium Addition (and Aerosol pH) Has a Dramatic Impact on the Volatility and Yield of Glyoxal Secondary Organic Aerosol, Environ. Sci. Technol., 48, 255-262, 2014.

Paciga, A. L., Riipinen, I., and Pandis, S. N.: Effect of Ammonia on the Volatility of Organic Diacids, Environ. Sci. Technol., 48, 13769-13775, 2014.

Paulot, F., Crounse, J. D., Kjaergaard, H. G., Kurten, A., St Clair, J. M., Seinfeld, J. H., and Wennberg, P. O.: Unexpected Epoxide Formation in the Gas-Phase Photooxidation of Isoprene, Science, 325, 730-733, 2009. 
Peeters, J., Vereecken, L., and Fantechi, G.: The detailed mechanism of the $\mathrm{OH}$-initiated atmospheric oxidation of [small alpha]pinene: a theoretical study, Phys. Chem. Chem. Phys., 3, 54895504, 2001.

Perri, M. J., Seitzinger, S., and Turpin, B. J.: Secondary organic aerosol production from aqueous photooxidation of glycolaldehyde: Laboratory experiments, Atmos. Environ., 43, 1487-1497, 2009.

Perri, M. J., Lim, Y. B., Seitzinger, S. P., and Turpin, B. J.: Organosulfates from glycolaldehyde in aqueous aerosols and clouds: Laboratory studies, Atmos. Environ., 44, 2658-2664, 2010.

Portmann, R. W., Solomon, S., and Hegerl, G. C.: Spatial and seasonal patterns in climate change, temperatures, and precipitation across the United States, P. Natl. Acad. Sci. USA, 106, 73247329, 2009.

Robinson, W. A., Reudy, R., and Hansen, J. E.: General circulation model simulations of recent cooling in the east-central United States, J. Geophys. Re.-Atmos., 107, 1-14, 2002.

Rossignol, S., Aregahegn, K. Z., Tinel, L., Fine, L., Nozière, B., and George, C.: Glyoxal Induced Atmospheric Photosensitized Chemistry Leading to Organic Aerosol Growth, Environ. Sci. Technol., 48, 3218-3227, 2014.

Sareen, N., Schwier, A. N., Shapiro, E. L., Mitroo, D., and McNeill, V. F.: Secondary organic material formed by methylglyoxal in aqueous aerosol mimics, Atmos. Chem. Phys., 10, 997-1016, doi:10.5194/acp-10-997-2010, 2010.

Saxena, P. and Hildemann, L.: Water-soluble organics in atmospheric particles: A critical review of the literature and application of thermodynamics to identify candidate compounds, J. Atmos. Chem., 24, 57-109, 1996.

Schwier, A. N., Sareen, N., Mitroo, D., Shapiro, E. L., and McNeill, V. F.: Glyoxal-Methylglyoxal Cross-Reactions in Secondary Organic Aerosol Formation, Environ. Sci. Technol., 44, 6174-6182, 2010.

Seinfeld, J. H. and Pankow, J. F.: Organic atmospheric particulate material, Annu. Rev. Phys. Chem., 54, 121-140, 2003.

Shapiro, E. L., Szprengiel, J., Sareen, N., Jen, C. N., Giordano, M. R., and McNeill, V. F.: Light-absorbing secondary organic material formed by glyoxal in aqueous aerosol mimics, Atmos. Chem. Phys., 9, 2289-2300, doi:10.5194/acp-9-2289-2009, 2009.

Sorooshian, A., Varutbangkul, V., Brechtel, F. J., Ervens, B., Feingold, G., Bahreini, R., Murphy, S. M., Holloway, J. S., Atlas, E. L., Buzorius, G., Jonsson, H., Flagan, R. C., and Seinfeld, J. H.: Oxalic acid in clear and cloudy atmospheres: Analysis of data from International Consortium for Atmospheric Research on Transport and Transformation 2004, J. Geophys. Re.-Atmos., 111, D23S45, doi:10.1029/2005JD006880, 2006.

Sorooshian, A., Murphy, S. M., Hersey, S., Bahreini, R., Jonsson, H., Flagan, R. C., and Seinfeld, J. H.: Constraining the contribution of organic acids and AMS $m / z 44$ to the organic aerosol budget: On the importance of meteorology, aerosol hygroscopicity, and region, Geophys. Res. Lett., 37, L21807, doi:10.1029/2010GL044951, 2010.
Spaulding, R. S., Schade, G. W., Goldstein, A. H., and Charles, M. J.: Characterization of secondary atmospheric photooxidation products: Evidence for biogenic and anthropogenic sources, J. Geophys. Re.-Atmos., 108, 4247, doi:10.1029/2002JD002478, 2003.

Stark, M. S.: Epoxidation of Alkenes by Peroxyl Radicals in the Gas Phase: Structure-Activity Relationships, J. Phys. Chem. A, 101, 8296-8301, 1997.

Sun, Y. L., Zhang, Q., Anastasio, C., and Sun, J.: Insights into secondary organic aerosol formed via aqueous-phase reactions of phenolic compounds based on high resolution mass spectrometry, Atmos. Chem. Phys., 10, 4809-4822, doi:10.5194/acp-104809-2010, 2010.

Surratt, J. D., Lewandowski, M., Offenberg, J. H., Jaoui, M., Kleindienst, T. E., Edney, E. O., and Seinfeld, J. H.: Effect of Acidity on Secondary Organic Aerosol Formation from Isoprene, Environ. Sci. Technol., 41, 5363-5369, 2007.

Tan, Y., Perri, M. J., Seitzinger, S. P., and Turpin, B. J.: Effects of Precursor Concentration and Acidic Sulfate in Aqueous Glyoxal$\mathrm{OH}$ Radical Oxidation and Implications for Secondary Organic Aerosol, Environ. Sci. Technol., 43, 8105-8112, 2009.

Tan, Y., Lim, Y. B., Altieri, K. E., Seitzinger, S. P., and Turpin, B. J.: Mechanisms leading to oligomers and SOA through aqueous photooxidation: insights from $\mathrm{OH}$ radical oxidation of acetic acid and methylglyoxal, Atmos. Chem. Phys., 12, 801-813, doi:10.5194/acp-12-801-2012, 2012.

Volkamer, R., Jimenez, J. L., San Martini, F., Dzepina, K., Zhang, Q., Salcedo, D., Molina, L. T., Worsnop, D. R., and Molina, M. J.: Secondary organic aerosol formation from anthropogenic air pollution: Rapid and higher than expected, Geophys. Res. Lett., 33, L17811, doi:10.1029/2006g1026899, 2006.

Volkamer, R., Martini, F. S., Molina, L. T., Salcedo, D., Jimenez, J. L., and Molina, M. J.: A missing sink for gas-phase glyoxal in Mexico City: Formation of secondary organic aerosol, Geophys. Res. Lett., 34, L19807, doi:10.1029/2007g1030752, 2007.

Volkamer, R., Ziemann, P. J., and Molina, M. J.: Secondary Organic Aerosol Formation from Acetylene $\left(\mathrm{C}_{2} \mathrm{H}_{2}\right)$ : seed effect on SOA yields due to organic photochemistry in the aerosol aqueous phase, Atmos. Chem. Phys., 9, 1907-1928, doi:10.5194/acp9-1907-2009, 2009.

Yao, X., Fang, M., and Chan, C. K.: Size distributions and formation of dicarboxylic acids in atmospheric particles, Atmos. Environ., 36, 2099-2107, 2002.

Zhang, Z., Lin, Y. H., Zhang, H., Surratt, J. D., Ball, L. M., and Gold, A.: Technical Note: Synthesis of isoprene atmospheric oxidation products: isomeric epoxydiols and the rearrangement products cis- and trans-3-methyl-3,4-dihydroxytetrahydrofuran, Atmos. Chem. Phys., 12, 8529-8535, doi:10.5194/acp-12-85292012, 2012. 